\title{
Simulating Nitrogen and Irrigation Effects on Wheat Production in Bangladesh under Changing Climate
}

\author{
Ranjit Sen1, Apurba Kanti Choudhury ${ }^{1}$, Sohela Akhter ${ }^{1}$, Sheikh Ishtiaque1, \\ Md. Abu Hena Sorwar Jahan1, Faruque Ahmed', Jatish Chandra Biswas², \\ Md. Maniruzzaman'2, Md. Main Uddin Miah'3 , Md. Mizanur Rahman³, \\ Naveen Kalra4, Md. Abdul Aziz¹, A. S. M. Mahbubur Rahman Khan'1 \\ ${ }^{1}$ Bangladesh Agricultural Research Institute, Gazipur, Bangladesh \\ ${ }^{2}$ Bangladesh Rice Research Institute, Gazipur, Bangladesh \\ ${ }^{3}$ Bangabandhu Sheikh Mujibur Rahman Agricultural University, Gazipur, Bangladesh \\ ${ }^{4}$ CRP-II Project, Krishi Gobeshona Foundation (KGF), Dhaka, Bangladesh \\ Email: senranjitbd@yahoo.com, ‘bd_apurba@yahoo.com, sohela_akhter@yahoo.com, ishtiaque@bari.gov.bd, \\ belal.bari@gmail.com, faruquebari@gmail.com, jatishb@yahoo.com, mzamaniwm@yahoo.com,mmumiahbsmrau@gmail.com, \\ mizan@bsmrau.edu.bd,drnkalra@gmail.com,m58abdulaziz@yahoo.com, mahbuburofrd@gmail.com
}

How to cite this paper: Sen, R., Choudhury, A.K., Akhter, S., Ishtiaque, S., Jahan, M.A.H.S., Ahmed, F., Biswas, J.C., Maniruzzaman, M., Miah, M.M.U., Rahman, M.M., Kalra, N., Aziz, M.A. and Khan, A.S.M.M.R. (2017) Simulating Nitrogen and Irrigation Effects on Wheat Production in Bangladesh under Changing Climate. American Journal of Plant Sciences, 8, 1593-1606.

https://doi.org/10.4236/ajps.2017.87110

Received: May 12, 2017

Accepted: June 18, 2017

Published: June 22, 2017

Copyright $\odot 2017$ by authors and Scientific Research Publishing Inc. This work is licensed under the Creative Commons Attribution International License (CC BY 4.0).

http://creativecommons.org/licenses/by/4.0/

\begin{abstract}
Climate change impacts are visible in Bangladesh which requires adoption of judicious crop management practices for sustainable agriculture. Crop simulation models are effective in this regard and can be used for optimizing water and nitrogen inputs for maximization of wheat yields. Two field studies were conducted at Bangladesh Agricultural Research Institute (BARI) for evaluating the effect of increased temperature on wheat production under variable water and $\mathrm{N}$ rates, through the use of DSSAT v4.6 model. Thirty years historic weather data and BARI Gom-26 wheat-cultivar coefficients, as generated through use of GLUE of DSSAT model, were used for evaluating the impact of temperature rise with variable rates of irrigation water and nitrogen. The effects of four levels of nitrogen $\left(0,40,80\right.$ and $\left.120 \mathrm{~kg} \mathrm{ha}^{-1}\right)$ and four irrigation levels [0 (no irrigation), 1,2 and 3] on wheat yield were evaluated under $0^{\circ} \mathrm{C}$, $1^{\circ} \mathrm{C}, 2^{\circ} \mathrm{C}$ and $3^{\circ} \mathrm{C}$ rise in temperature. Simulation results indicated that wheat yield increased with increase in nitrogen application rate, but decreased with the temperature rise. Crop growing duration was reduced by about five days for each degree rise in temperature, irrespective of levels of irrigation water and nitrogen-rates. In general, there was yield reduction of 8.13, 16.77 and $24.97 \%$ with increased temperature of $1^{\circ} \mathrm{C}, 2^{\circ} \mathrm{C}$ and $3^{\circ} \mathrm{C}$, respectively, when compared with no temperature rise treatment. For interaction of temperature rise- $\mathrm{N}$ dose, the magnitude of yield decline under temperature rise was higher with increased dose of $\mathrm{N}$. Agronomic $\mathrm{N}$ use efficiency at different $\mathrm{N}$ rates and
\end{abstract}


temperature rise level were calculated. $\mathrm{N}$ use efficiency decreases with the increase in temperature rise and the highest $\left(29.95 \mathrm{~kg}_{\text {grain }} \mathrm{kg}^{-1} \mathrm{~N}\right)$ was obtained from $40 \mathrm{~kg} \mathrm{~N} \mathrm{ha}^{-1}$ treated plot with $0^{\circ} \mathrm{C}$ temperature rise i.e. existing atmospheric temperature. Simulation results indicated increase in wheat yield with higher levels of irrigation water, and interaction of irrigation level with temperature rise was significant. Irrigation use efficiency decreases with the increase in temperature rise. From the present study, it was seen that the interaction of temperature rise with varying levels of $\mathrm{N}$ and irrigation water was significant, and there is a need to design the appropriate inputs' management, as the adaptation strategy, to sustain the wheat yield under climate change situation.

\section{Keywords}

Climate Change, Wheat, Temperature Rise, Irrigation, Nitrogen, Bangladesh

\section{Introduction}

Crop growth models play important role in agricultural research, especially in the decision system of technology development, research management and policy options [1]. It helps in taking decision regarding different crop management practices like nitrogen application and irrigation scheduling which influences crop yield in a greater extent. Field experiments on different crop management practices, to find out best management options, is costly, time consuming and laborious. Crop simulation model can help in selecting specific management options out of number of strategies [2]. In agro-climatic zone where nitrogen and irrigation are limiting factor for crop production, crop simulation models are especially useful as the outcome of management strategies are strongly influenced by inter-annual climatic variability and inter-zone soil variability. Besides, strategies to mitigate the adverse effects of water stress on crop yields and potential interactions among other inputs could easily be tested through use of simulation models in order to identify the best options [3] [4].

Wheat is the second most important cereal crop in Bangladesh and environment friendly in terms of irrigation water requirement, but sensitive to increased temperature. Nitrogen and irrigation water management not only help in achieving improved wheat yield, but it also mitigates greenhouse gas (GHG) emission from the crop fields. Though wheat is grown even under reduced irrigation conditions or residual soil moisture, climate change impacts may cause reduced water availability in future agriculture of Bangladesh and there is a need to identify the effect of soil moisture availability on growth and yield of wheat. Simulation study through crop modelling can predict crop performance against raising temperature scenarios of Bangladesh, by also integrating the interaction effect of other biotic and abiotic stresses.

Nitrogen is the key nutrient for wheat production. Crops grown in Bangladesh are more responsive to nitrogen than other nutrients. Similarly irrigation is 
an important input for crop production. Wheat grows in winter season of Bangladesh when no rainfall occurs and thereby less moisture prevail in the soil. So irrigation is essential for better wheat production. But both nitrogen and irrigation are expensive input for crop production. Field experiments for quantifying optimal crop $\mathrm{N}$ and irrigation water requirement are time-consuming, require many years of trials at multiple locations [5]. Judicious use of nitrogen and irrigation are essential for wheat production. DSSAT model can quantify nitrogen and irrigation water requirement of wheat. It will save time, money and energy and will increase farmers profit.

Decision Support System for Agrotechnology Transfer (DSSAT v4.6) is a popular modelling system [6] [7], which includes more than 40 crops under the Cropping System Model (CSM). CERES-Wheat Model was one of them which can predict the effects of cultivar, plant population, weather, soil water and nitrogen on crop growth, development and yield, in relation to their environment [8] [9]. The DSSAT has been successfully used under various climates and management strategies worldwide [10] [11] [12], in fertilizer $\mathrm{N}$ management [13] [14] [15] [16] [17], and environmental impact assessment [18]. Studies related to genotypic and environmental interaction over the entire crop's life cycle have also been done in recent past [3] [19], which indicated that DSSAT can be utilized to predict wheat performances against future climate change scenarios for Bangladesh. In the present study, simulation studies, by using DSSAT version 4.6 , were undertaken to predict performances of wheat with rising temperatures under variable nitrogen rates and irrigation water supplies.

\section{Materials and Methods}

\subsection{Experimental Site}

The simulation study was conducted at Bangladesh Agricultural Research Institute (BARI) by using DSSAT v.4.6 model during growing season of 2016-2017 at Dinajpur $\left(25.63^{\circ} \mathrm{N}\right.$ and $88.63^{\circ} \mathrm{E}$ and $39 \mathrm{~m}$ above mean sea level), which is the major wheat growing region of Bangladesh. Soil properties of the test site are given in Table 1(a) and Table 1(b). The test soil belongs to Grey Flood Plain Soil, having sandy loam in texture. Warm humid climate, in general, prevails in Dinajpur, with the average maximum and minimum temperatures, total rainfall and average sunshine hours as presented in Table 2.

\subsection{Brief Description of DSSAT Model}

DSSAT is a comprehensive crop growth model which includes more than 40 crops. The Crop Estimation Resource and Environment Synthesis (CERES)Wheat model was one of the models developed through the International Benchmark Sites Network for Agrotechnology Transfer (IBSNAT) project which can simulate growth and yield of wheat varieties under all agro-climatic conditions [20]. The latest version CERES-Wheat model (DSSAT v 4.6) was released in $1^{\text {st }}$ September, 2015. The model simulate growth and yield of crop on the basis of understanding of plant, soil, wheat and management interaction. The model 
Table 1. (a) Physical properties of experimental soil; (b) chemical properties of experimental soil.

(a)

\begin{tabular}{ccccc}
\hline Soil layer $(\mathrm{cm})$ & Sand (\%) & Silt (\%) & Clay (\%) & Bulk density $\left(\mathrm{g} \cdot \mathrm{cm}^{-3}\right)$ \\
\hline $0-15$ & 61.0 & 22.7 & 16.3 & 1.49 \\
$15-30$ & 66.3 & 11.7 & 27.3 & 1.57 \\
$30-60$ & 58.3 & 11.0 & 30.7 & 1.59 \\
$60-90$ & 55.9 & 9.4 & 34.7 & 1.61 \\
$90-120$ & 67.3 & 14.4 & 18.3 & 1.62 \\
$120-150$ & 74.3 & 6.4 & 19.3 & 1.67 \\
$150-180$ & 74.3 & 6.3 & 19.4 & 1.69
\end{tabular}

(b)

\begin{tabular}{cccccccc}
\hline $\begin{array}{c}\text { Soil layer } \\
(\mathrm{cm})\end{array}$ & $\mathrm{pH}$ & $\begin{array}{c}\text { Organic } \\
\text { carbon (\%) }\end{array}$ & $\begin{array}{c}\text { Total } \mathrm{N} \\
(\%)\end{array}$ & $\begin{array}{c}\mathrm{NO}_{3}^{-} \mathrm{N} \\
\left(\mathrm{mg} \cdot \mathrm{kg}^{-1}\right)\end{array}$ & $\begin{array}{c}\mathrm{NH}_{4}^{+} \mathrm{N} \\
\left(\mathrm{mg} \cdot \mathrm{kg}^{-1}\right)\end{array}$ & $\begin{array}{c}\text { Available } \\
\text { phosphorous } \\
\left(\mathrm{mg} \cdot \mathrm{kg}^{-1}\right)\end{array}$ & $\begin{array}{c}\text { Available } \\
\text { potassium } \\
\left(\mathrm{mg} \cdot \mathrm{kg}^{-1}\right)\end{array}$ \\
\hline $0-15$ & 6.1 & 0.49 & 0.05 & 9.8 & 2.0 & 6.27 & 0.26 \\
$15-30$ & 6.2 & 0.28 & 0.03 & 7.3 & 2.1 & 6.03 & 0.24 \\
$30-60$ & 6.2 & 0.19 & 0.02 & 5.1 & 2.2 & 5.18 & 0.22 \\
$60-90$ & 6.3 & 0.14 & 0.01 & 4.7 & 2.5 & 4.83 & 0.19 \\
$90-120$ & 6.4 & 0.13 & 0.01 & 4.3 & 2.7 & 3.98 & 0.16 \\
$120-150$ & 6.5 & 0.12 & 0.01 & 3.5 & 3.2 & 3.19 & 0.15 \\
$150-180$ & 6.7 & 0.10 & 0.01 & 3.0 & 3.4 & 2.88 & 0.13 \\
\hline
\end{tabular}

Table 2. Climate (normals) of Dinajpur (from past 30 year's average) during the growing season of wheat crop.

\begin{tabular}{ccccc}
\hline \multirow{2}{*}{ Month } & \multicolumn{2}{c}{ Average temperature $\left({ }^{\circ} \mathrm{C}\right)$} & & \\
\cline { 2 - 4 } & Maximum & Minimum & Total rainfall $(\mathrm{mm})$ & Sunshine hour \\
\hline November & 29.0 & 16.6 & 15.2 & 7.82 \\
December & 25.1 & 12.2 & 6.9 & 6.49 \\
January & 22.9 & 10.4 & 8.8 & 5.94 \\
February & 26.5 & 13.0 & 12.7 & 7.51 \\
March & 30.9 & 17.4 & 11.4 & 8.09 \\
April & 32.9 & 21.1 & 65.7 & 7.41 \\
\hline
\end{tabular}

includes various tools like XBuild to create and modify experiment files, GBuild for graphing of outputs, SBuild for soil database, Weatherman for weather data and GLUE for genetic coefficient. Data on weather, soil and crop characteristics and various crop management options were used as input data. Solar radiation, air temperature (maximum and minimum in ${ }^{\circ} \mathrm{C}$ ) and precipitation $(\mathrm{mm})$ were used as weather data while soil physical properties like texture, structure, bulk 
density, water holding capacity and chemical properties like $\mathrm{pH}, \mathrm{N}, \mathrm{P}, \mathrm{K}$ content were used as soil data. Experimental data on time series biomass and leaf area index were used as crop data.

In order to simulate yields under changing temperature scenarios, the CERESWheat model in DSSAT was calibrated and validated. Climatic data were collected from the weather station of Dinajpur, which operates under the Department of Metrology, Government of Bangladesh. The input files, such as weather file, soil file, $\mathrm{X}$ file (experimental file), A file (average measured data file) and $\mathrm{T}$ file (seasonal file) were prepared for using CERES-Wheat model to predict wheat yield under temperature rise and variable water and nitrogen inputs.

\subsection{Simulating Temperature Rise, Variable Irrigation and Nitrogen Inputs Effects}

Two separate simulated studies were carried out to predict rise in temperature impact on wheat yield. In first study, the effects of rising temperature $\left(0^{\circ} \mathrm{C}, 1^{\circ} \mathrm{C}\right.$, $2^{\circ} \mathrm{C}$ and $3^{\circ} \mathrm{C}$ ) on wheat yield under variable nitrogen inputs viz. $0,40,80$ and $120 \mathrm{~kg} \mathrm{~N} \mathrm{ha}^{-1}$ were investigated. In second study, variable irrigation levels viz. 0 , 1,2 and 3 to create differential soil water regimes, in combination with temperature rise scenarios of $0^{\circ} \mathrm{C}, 1^{\circ} \mathrm{C}, 2^{\circ} \mathrm{C}$ and $3^{\circ} \mathrm{C}$, were used to simulate the effect on growth and yield of wheat crop.

\subsection{Test Cultivar of Wheat}

The simulation runs were made with wheat variety, BARI Gom-26, through conducted field trials, and crop coefficients were generated through run of tool GLUE of DSSAT. Genetic coefficients were computed, and performance evaluation was done through comparison of observed and simulated values for various field experiments compiled from BARI sub-stations in various production environments of Bangladesh.

\subsection{Model Application}

Predicted wheat yield was generated using seasonal run from 1980 to 2010. The scenarios were developed to assess the sensitivity of the crop to rising temperature with varying level of $\mathrm{N}$ and irrigation number. Calibrated DSSAT model for wheat grown in Bangladesh environment was used to evaluate the impact of these scenarios of interaction of temperature with varying irrigation water and nitrogen inputs, and the outputs were analyzed using graphical techniques to compare climate change effect on growth and yield of wheat.

\subsection{Agronomic N Use Efficiency}

Agronomic $\mathrm{N}$ use efficiency at different $\mathrm{N}$ rate and temperature rise level was calculated with the following equation [21]:

$$
\text { Agronomic } N \text { use efficiency }=\left(G Y_{F}-G F_{0}\right) / F_{N}
$$

where $G Y_{F}=$ Grain yield $\left(\mathrm{kg} \mathrm{ha}^{-1}\right)$ in $N$-fertilized plot, $G Y_{0}=$ Grain yield $(\mathrm{kg}$ $\mathrm{ha}^{-1}$ ) in zero $N$-fertilized plot and $\mathrm{F}_{\mathrm{N}}$ was total fertilizer $\mathrm{N}$ applied $\left(\mathrm{kg} \mathrm{ha}^{-1}\right)$. 


\subsection{Irrigation Use Efficiency}

Irrigation use efficiency at different irrigation and temperature rise level was calculated with the following equation:

$$
\text { Irrigation use efficiency }=\left(G Y_{I}-G I_{0}\right) / I_{N}
$$

where $G Y_{I}=$ Grain yield $\left(\mathrm{kg} \mathrm{ha}^{-1}\right)$ in irrigated plot, $G I_{0}=$ Grain yield $\left(\mathrm{kg} \mathrm{ha}^{-1}\right)$ in unirrigated plot and $I_{N}$ was total number of irrigation.

\section{Results and Discussion}

\subsection{Calibration of CERES-Wheat Model}

With the help of several wheat trials (with dates of sowing, irrigation and nitrogen rates), the genetic coefficients were computed by use of tool GLUE of DSSAT (Table 3). The performance of the CERES-Wheat model was evaluated through comparison of simulated verses observed yield of wheat.

The P1V is optimum vernalizing temperature, required for vernalization expressed in days, PID indicates photoperiod response (\% reduction in rate/10 h drop in pp), P5 is grain filling (excluding lag) phase duration $\left({ }^{\circ} \mathrm{C}-\mathrm{d}\right) . \mathrm{G} 1, \mathrm{G} 2$ and G3 means kernel number per unit canopy weight at anthesis (\#/g), standard kernel size for wheat grown under optimum conditions (mg) and standard, nonstressed mature tiller weight (including grain) $(\mathrm{g} \mathrm{dwt})$; respectively. PHINT indicates interval between successive leaf tip appearances expressed in ${ }^{\circ} \mathrm{C}$-d.

Figure 1 shows the performance evaluation of the CERES-Wheat model through comparison of observed verses simulated yield of wheat. The trend line was almost close with the 1:1 line, indicating that the model was performing well for simulating the yield of wheat grown in Bangladesh environment. The trend line showed satisfactory predictability, as seen through very high $\mathrm{R}^{2}$ value. The percent error of estimate lied within the range of- $10.9 \%$ to $5.3 \%$, indicating that the model can be taken to application platform for evaluating the interaction of rise in temperature with variable inputs of irrigation water and nitrogen.

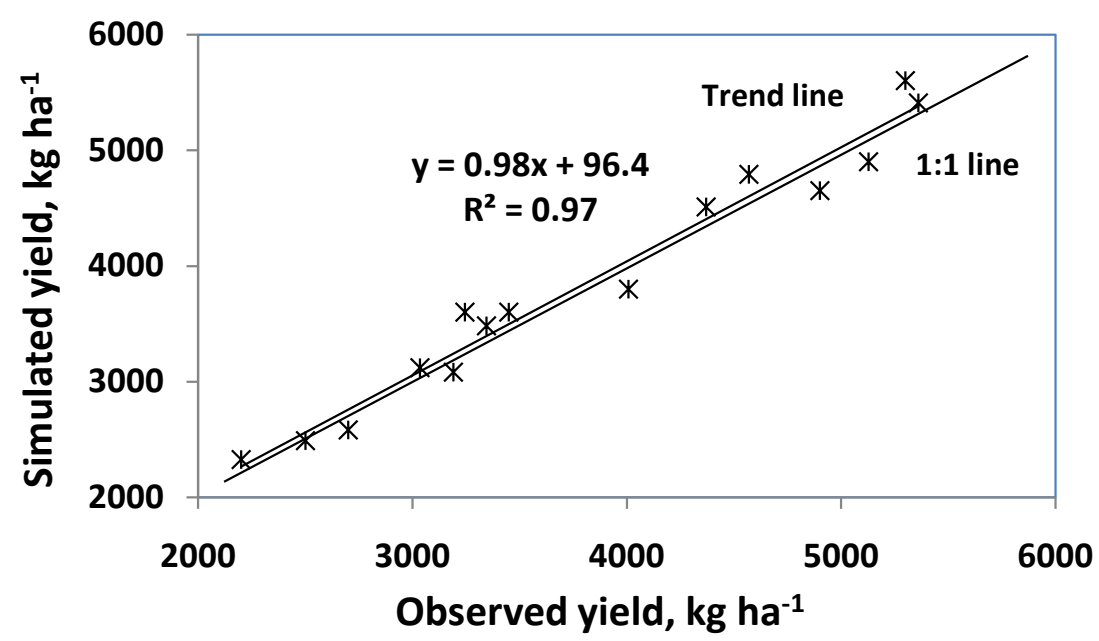

Figure 1. Performance evaluation of CERES-Wheat model through comparison of observed verses simulated yield of wheat cultivar, BARI Gom 26. 
Table 3. Genetic coefficient of different wheat varieties.

\begin{tabular}{cccccccc}
\hline Variety & P1V & P1D & P5 & G1 & G2 & G3 & PHINT \\
\hline BARI Gom-26 & 0 & 92 & 730 & 23 & 46 & 3.8 & 70 \\
\hline
\end{tabular}

\subsection{Effect of Temperature Rise and Variable Nitrogen Inputs on Growth and Yield of Wheat}

Simulation results, with long term historic weather, indicated that maximum leaf area index (LAImax) increased with the increase in $\mathrm{N}$ rate and decrease with temperature rise (Figure 2). The maximum LAImax (3.6) was obtained from $120 \mathrm{~kg} \mathrm{~N}^{-1}$ with no temperature rise. With $1^{\circ} \mathrm{C}$ temperature rise, the maximum LAI values were $1.8,2.6,2.8$ and 3.0 ; with $2^{\circ} \mathrm{C}$ temperature rise, the values were 1.6, 2.4, 2.5 and 2.6; and with $3^{\circ} \mathrm{C}$ temperature rise, the values were 1.5, 1.9, 2.1 and 2.3 under $\mathrm{N}$ application dose of $0,40,80$ and $120 \mathrm{~kg} \mathrm{~N}^{-1}$, respectively. The lowest value of LAImax was obtained under temperature increase of $3^{\circ} \mathrm{C}$ with no nitrogen- $\mathrm{N}$ input. Maximum LAI, usually noticed at anthesis stage, has one to one correspondence with the final wheat yield. Irrespective of nitrogen level, about $13.80 \%, 25.46 \%$ and $34.32 \%$ reduction in the LAImax of BARI Gom-26 was observed in $1^{\circ} \mathrm{C}, 2^{\circ} \mathrm{C}$ and $3^{\circ} \mathrm{C}$ temperature rise, respectively compared to no temperature rise treatment.

The highest values of days to maturity (i.e. $114 \mathrm{~d}$ ) was obtained under no temperature rise and the lowest value of $100 \mathrm{~d}$ was obtained under $3^{\circ} \mathrm{C}$ rise in temperature treatment, with corresponding values of $110 \mathrm{~d}$ and $105 \mathrm{~d}$ under $1{ }^{\circ} \mathrm{C}$ and $2^{\circ} \mathrm{C}$ temperature, respectively (Figure 3 ). Days to maturity decreased with the increase in temperature, subsequently resulting in lower grain yield. In general, wheat crop matured early by about 5 days for every increase in temperature of $1^{\circ} \mathrm{C}$. The results were in agreement with the findings of Kalra et al. [22], where they observed reduction in duration of the wheat crop by $5-6$ days per degree rise in temperature by running INFOCROP model [23] [24].

Effect of rise in temperature and nitrogen- $\mathrm{N}$ application on grain yield of wheat is shown in Figure 4. Grain yield of wheat increased with the increase of nitrogen application rate and decreased with rising temperature, and results were in agreement with Aggarwal and Kalra [25], where they observed higher wheat yield with increase in N-input by running Wheat Growth Simulator, WTGROWS for New Delhi environment. Wheat yield generally gets stagnant after $150 \mathrm{~kg} \mathrm{~N} \mathrm{ha}^{-1}$, and use of simulation tool helps in optimizing the $\mathrm{N}$-input for a given production environment. In the present study, highest simulated grain yield was under $120 \mathrm{~kg} \mathrm{ha}^{-1}$ with no temperature rise. Lowest grain yield was noticed under no nitrogen- $\mathrm{N}$ dose with $3^{\circ} \mathrm{C}$ temperature rise scenario. Irrespective of nitrogen level, about $8.13 \%, 16.77 \%$ and $24.97 \%$ reduction in grain yield of BARI Gom-26 was observed under $1^{\circ} \mathrm{C}, 2^{\circ} \mathrm{C}$ and $3^{\circ} \mathrm{C}$ temperature rise, respectively when compared with no temperature rise treatment. Because when temperature increased, the soil $\mathrm{N}$ losses such as denitrification, volatilization and $\mathrm{N}_{2} \mathrm{O}$ emission increased, whereas grain and biomass yields decreased [26]. For 


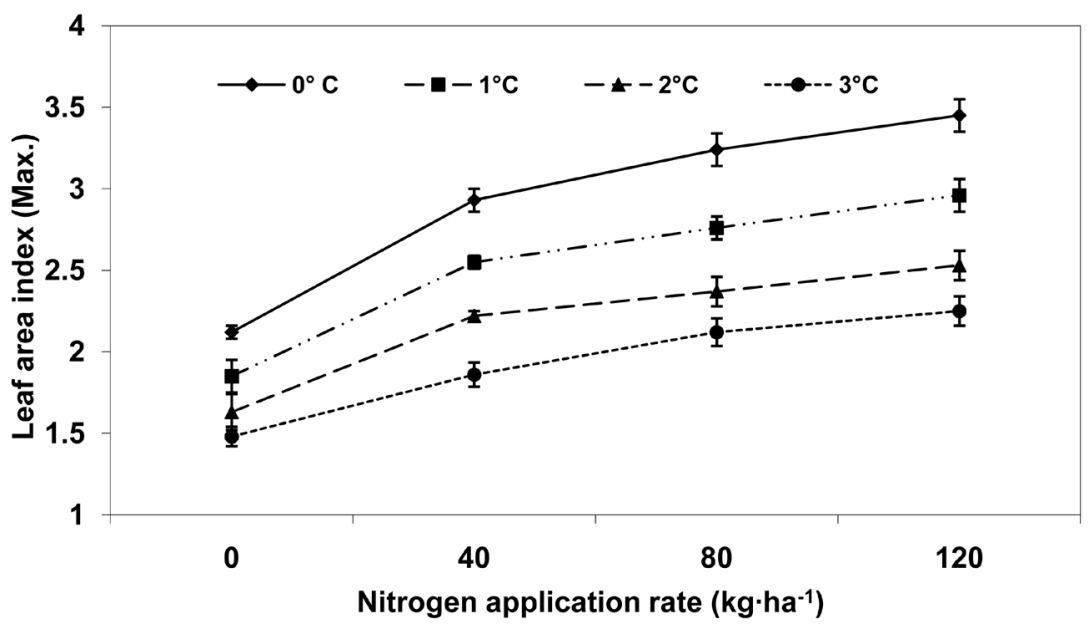

Figure 2. Effect of rise in temperature and $\mathrm{N}$ rates on maximum leaf area index of wheat (30 years historic weather run).

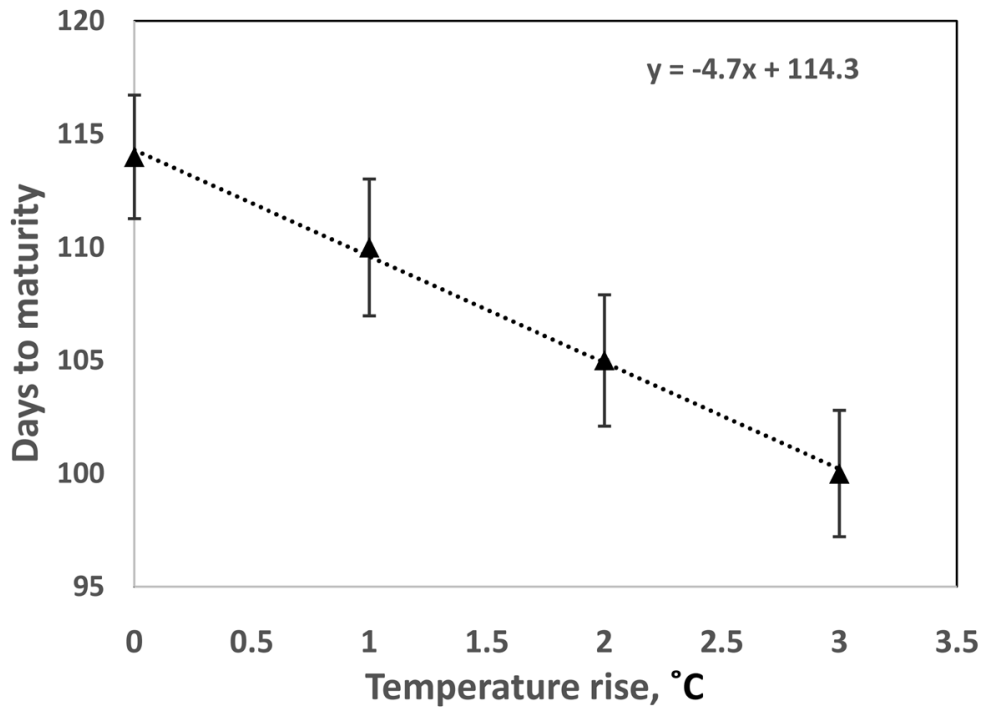

Figure 3. Effect of rise in temperature on days to maturity of wheat (30 years historic weather run).

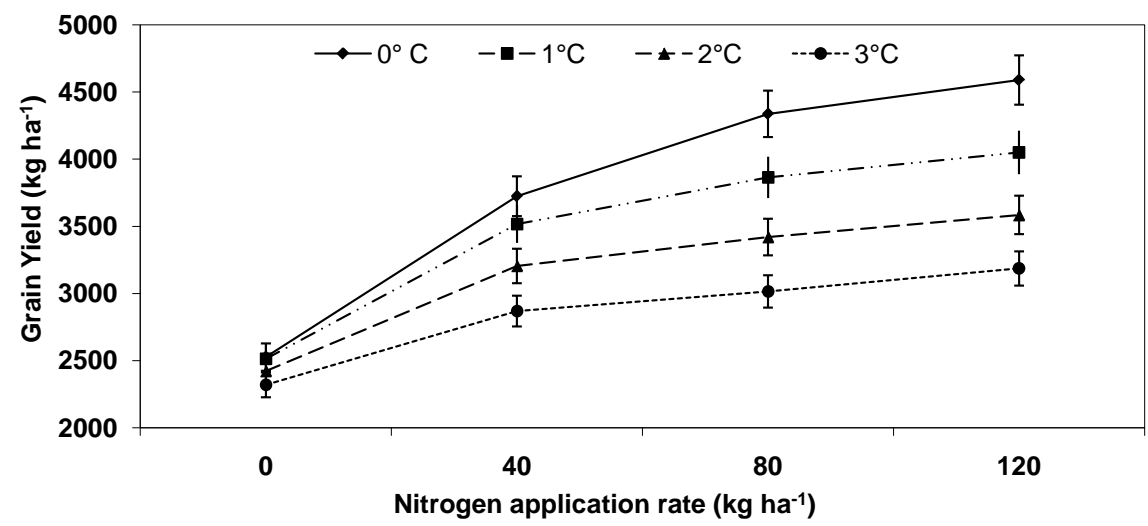

Figure 4. Effect of rise in temperature and nitrogen application on grain yield of wheat (30 years historic weather run). 
interaction of temperature rise- $\mathrm{N}$ dose, the magnitude of yield decline under temperature rise was higher with increased dose of $\mathrm{N}$.

Agronomic $\mathrm{N}$ use efficiency at different $\mathrm{N}$ rates and temperature rise level (compare with $0 \mathrm{~kg} \mathrm{~N} \mathrm{ha}^{-1}$ ) were calculated and presented in Table 4. Agronomic $\mathrm{N}$ use efficiency decrease with both the increase in temperature rise and $\mathrm{N}$-rates. In $0^{\circ} \mathrm{C}$ temperature rise i.e. existing atmospheric temperature, $\mathrm{N}$ use efficiency ranged from 17.20 to $29.95 \mathrm{~kg}_{\text {grain }} \mathrm{kg}^{-1} \mathrm{~N}$ while in $1^{\circ} \mathrm{C}$ temperature rise, it ranged from 12.80 to $25.08 \mathrm{~kg}_{\text {grain }} \mathrm{kg}^{-1} \mathrm{~N}$. In increased temperature $\mathrm{N}$ use efficiency decreased gradually. In $2^{\circ} \mathrm{C}$ temperature rise, $\mathrm{N}$ use efficiency ranged from 9.68 to $19.58 \mathrm{~kg}$ grain $\mathrm{kg}^{-1} \mathrm{~N}$ while in $3^{\circ} \mathrm{C}$ temperature rise, it ranged from 7.22 to $13.73 \mathrm{~kg}_{\text {grain }} \mathrm{kg}^{-1} \mathrm{~N}$. Among the twelve $\mathrm{N}$ use efficiencies, highest $\left(29.95 \mathrm{~kg}_{\text {grain }} \mathrm{kg}^{-1} \mathrm{~N}\right.$ ) was obtained from $40 \mathrm{~kg} \mathrm{ha}^{-1} \mathrm{~N}$ rate with $0^{\circ} \mathrm{C}$ temperature rise and lowest $\left(7.22 \mathrm{~kg}\right.$ grain $\left.\mathrm{kg}^{-1} \mathrm{~N}\right)$ was obtained from $120 \mathrm{~kg}$ $\mathrm{ha}^{-1} \mathrm{~N}$ rate with $3^{\circ} \mathrm{C}$ temperature rise. Due to yield reduction in increased temperature level $\mathrm{N}$-use efficiency was lower in higher temperature level and due to higher amount of $\mathrm{N}$ in high $\mathrm{N}$ rates, $\mathrm{N}$-use efficiency was lower in high $\mathrm{N}$ rates. These findings were at parity with the findings of Krupnik et al. [21] who obtained higher agronomic $\mathrm{N}$ use efficiency in wheat in Bangladesh with lower $\mathrm{N}$ rates.

\subsection{Effect of Temperature Rise and Variable Irrigation Levels on Growth and Yield of Wheat}

Effect of rise in temperature and variable irrigation levels on maximum leaf area index at anthesis (LAI) of wheat is shown in Figure 5. Four levels of temperature rise $\left(0^{\circ} \mathrm{C}, 1^{\circ} \mathrm{C}, 2^{\circ} \mathrm{C}\right.$ and $\left.3^{\circ} \mathrm{C}\right)$ and four levels of irrigation application (0-rainfed, 1 irrigation at CRI, 2 irrigations at CRI and flowering, and 3 irrigations at CRI, maximum jointing and flowering) were imposed in the model to simulate LAI of wheat. Maximum leaf area index (LAImax) increased with the increase in irrigation and decrease with temperature rise (Figure 5). The highest LAImax value of 3.42 was obtained under three irrigation levels with no temperature rise treatment. With $1^{\circ} \mathrm{C}$ temperature rise, the LAImax values were 1.22, 1.96, 2.90 and 3.18 ; corresponding values with $2^{\circ} \mathrm{C}$ were $1.16,1.82,2.68$ and 2.86 and with $3^{\circ} \mathrm{C}$ temperature rise, the LAImax values were 1.07, 1.74, 2.52 and 2.65 under $0,1,2$ and 3 irrigation levels, respectively. The lowest LAImax of 1.07 was obtained if temperature increased by $3{ }^{\circ} \mathrm{C}$ having no irrigation. Irrespective of irrigation level, about $5.60 \%, 13.15 \%$ and $18.65 \%$ reduction in maximum leaf area index (at anthesis) of BARI Gom-26 was noticed under $1^{\circ} \mathrm{C}, 2^{\circ} \mathrm{C}$ and $3^{\circ} \mathrm{C}$ temperature rise, respectively compared to no temperature rise treatment.

Table 4. Agronomic $\mathrm{N}$ use efficiency $\left(\mathrm{kg}\right.$ grain $\left.\mathrm{kg}^{-1} \mathrm{~N}\right)$ at different $\mathrm{N}$ rates and temperature rise level.

\begin{tabular}{ccccc}
\hline \multirow{2}{*}{$\mathrm{N}$ rate $\left(\mathrm{kg} \mathrm{ha}^{-1}\right)$} & \multicolumn{4}{c}{ Temperature rise level } \\
\cline { 2 - 5 } & $0^{\circ} \mathrm{C}$ & $1^{\circ} \mathrm{C}$ & $2^{\circ} \mathrm{C}$ & $3^{\circ} \mathrm{C}$ \\
\hline 40 & 29.95 & 25.08 & 19.58 & 13.73 \\
80 & 22.64 & 16.89 & 12.48 & 8.70 \\
120 & 17.20 & 12.80 & 9.68 & 7.22 \\
\hline
\end{tabular}




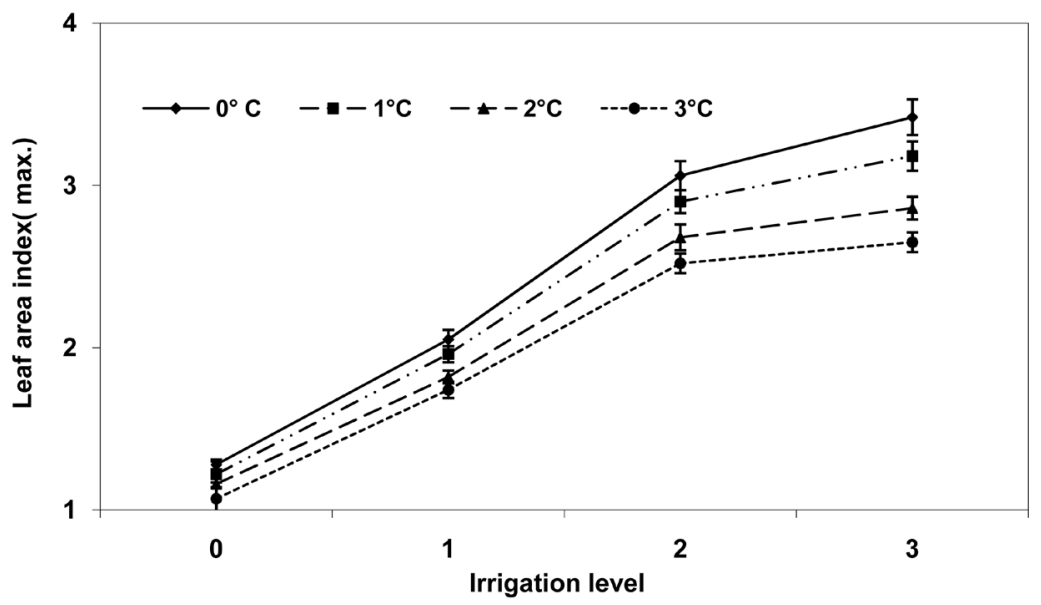

Figure 5. Interaction of temperature rise and variable irrigation levels on maximum leaf area index (LAI) at anthesis (30 years historic weather run).

Simulation results indicated that grain yield of wheat increased with the increase of irrigation level, but decreased with rise in temperature (Figure 6). Similar findings were reported by Aggarwal and Kalra [25] and Kalra et al. [22], where simulated wheat yields increased with increased level of irrigation and the growth rate of yield decreased when the number of irrigation increased beyond 3. Interaction between temperature rise and irrigation levels was significant; the extent of reduction with temperature was higher as the irrigation levels increased. The result clearly indicated that reduction in yield with temperature rise was more pronounced under adequately irrigated condition, which primarily was due to reduction in duration of the crop, in particular grain growing duration. Highest grain yield of $4535 \mathrm{~kg} \mathrm{ha}^{-1}$ was noticed in 3 irrigation with no temperature rise treatment and lowest grain yield of $1119 \mathrm{~kg} \mathrm{ha}^{-1}$ was noticed in no irrigation with $3^{\circ} \mathrm{C}$ temperature rise treatment. Irrespective of irrigation level, $5.60 \%, 13.15 \%$ and $18.65 \%$ yield reduction of wheat was observed under $1^{\circ} \mathrm{C}$, $2^{\circ} \mathrm{C}$ and $3{ }^{\circ} \mathrm{C}$ temperature rise treatments, when compared with no irrigation treatment. The extent of reduction in wheat yield due to temperature rise was $0.42 \mathrm{t} / \mathrm{ha} /{ }^{\circ} \mathrm{C}$ in India [26].

Irrigation use efficiency at different irrigations and temperature rise level (compare with 0 irrigation i.e. un-irrigated plot) were calculated and presented in Table 5. In all the irrigated plot, irrigation use efficiency decrease with the increase in temperature rise. In $0^{\circ} \mathrm{C}$ temperature rise i.e. existing atmospheric temperature, irrigation use efficiency ranged from 750 to $1223 \mathrm{~kg}$ grain/irrigation while in $1^{\circ} \mathrm{C}$ temperature rise, it ranged from 737 to $1155 \mathrm{~kg}$ grain/irrigation. In increased temperature irrigation use efficiency decreased gradually. In $2^{\circ} \mathrm{C}$ temperature rise, irrigation use efficiency ranged from 714 to $1080 \mathrm{~kg}$ grain/ irrigation while in $3^{\circ} \mathrm{C}$ temperature rise, it ranged from 695 to $974 \mathrm{~kg}$ grain/irrigation. Highest irrigation use efficiency (1223 kg grain/irrigation) was obtained from 2 irrigation level with $0^{\circ} \mathrm{C}$ temperature rise and lowest irrigation use efficiency (695 kg grain/irrigation) was obtained from 1 irrigation with $3^{\circ} \mathrm{C}$ temperature rise. Due to yield reduction in increased temperature level irrigation use 


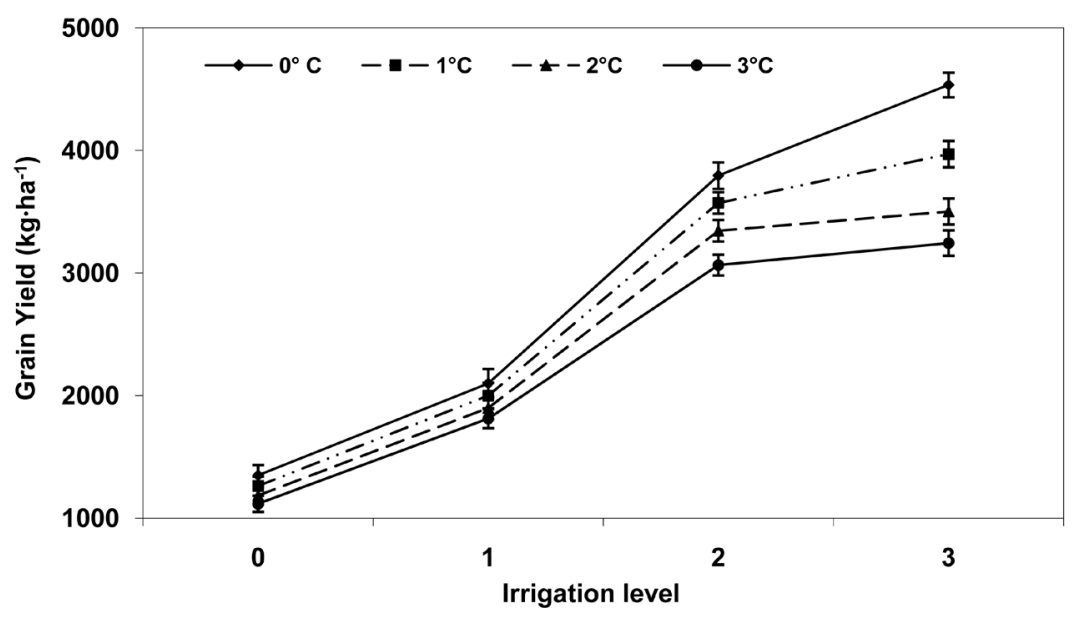

Figure 6. Effect of rise in temperature and irrigation application on grain yield of wheat (30 years historic weather run).

Table 5. Irrigation use efficiency (kg grain/irrigation) at different irrigation levels and temperature rise level.

\begin{tabular}{ccccc}
\hline \multirow{2}{*}{ Irrigation level } & \multicolumn{4}{c}{ Temperature rise level } \\
\cline { 2 - 5 } & $0^{\circ} \mathrm{C}$ & $1^{\circ} \mathrm{C}$ & $2^{\circ} \mathrm{C}$ & $3^{\circ} \mathrm{C}$ \\
\hline 1 & 750 & 737 & 714 & 695 \\
2 & 1223 & 1155 & 1080 & 974 \\
3 & 1061 & 902 & 772 & 709 \\
\hline
\end{tabular}

efficiency was lowest in $3^{\circ} \mathrm{C}$ temperature rise followed by $2^{\circ} \mathrm{C}$ and $1^{\circ} \mathrm{C}$ temperature rise. Highest irrigation use efficiency was obtained from $0^{\circ} \mathrm{C}$ temperature rise i.e. existing atmospheric temperature. Irrigation use efficiency increase with the increase in irrigation level upto two irrigation and decreased thereafter. Because between 1 to 2 irrigation, wheat yield increased highly (Figure 6) availing all the soil nutrient to plants. Between 0 to 1 irrigation, soil nutrients were underutilized resulting lower yield increase thereby lower irrigation use efficiency. On the other hand, at 3 irrigation level, irrigation use efficiency was also lower. Grain yield increasing rate is lower between 2 to 3 irrigation level resulting moderate irrigation use efficiency. These findings were at parity with the findings of Sen et al. [27] where irrigation use efficiency in wheat crop increase upto 2 irrigation and decrease thereafter.

\section{Conclusion}

Climate change and its variability are major concerns in Bangladesh. Rising temperature is the main phenomena in climate change. Wheat is an important crop of the country, and there is a need to evaluate the impact of temperature rise on growth and yield under variable rates of irrigation water and nitrogen. DSSAT version 4.6 was calibrated for important wheat cultivar and subsequently taken to simulate the effect of temperature rise with irrigation water and nitrogen interaction at Dinajpur. Historic weather dataset, soil parameters were used. 
Wheat yield decreased with increase in temperature, due to reduced duration of the crop and considerable reduction in the maximum leaf area index at flowering. Simulated yield of wheat increased with increased levels of irrigation water and nitrogen. The interaction of rise in temperature with the irrigation water and nitrogen inputs was significant, and the crop simulation tools could successfully guide in optimizing these major inputs with regard to temperature rise scenarios. Simulation of nitrogen- $\mathrm{N}$ and irrigation water management strategies using DSSAT models can, therefore, lead to better irrigation water and nitrogenous fertilizer decision-making.

\section{Acknowledgements}

The authors gratefully acknowledge the financial support provided by Bangladesh Krshi Gobeshona Foundation (KGF) under the project entitled "Modelling Climate Change Impact on Agriculture and Developing Mitigation and Adaptation Strategies for Sustaining Agricultural Production in Bangladesh" executed by BARI, BRRI and BSMARU.

\section{Conflict of Interests}

The authors declare no conflict of interest.

\section{References}

[1] Boote, K.J., Jones, J.W. and Pickering, N.B. (1996) Potential Uses and Limitations of Crop Models. Agronomy Journal, 88, 704-716. https://doi.org/10.2134/agronj1996.00021962008800050005x

[2] Paz, J.O., Batchelor, W.D., Babcock, B.A., Colvin, T.S., Logsdon, S.D., Kaspar, T.C. and Karlen, D.L. (1999) Model-Based Technique to Determine Variable Rate Nitrogen for Corn. Agricultural Systems, 61, 69-75.

[3] Ghaffari, A., Cook, H.F. and Lee, H.C. (2001) Simulating Winter Wheat Yields under Temperate Conditions: Exploring Different Management Scenarios. European Journal of Agronomy, 15, 231-240.

[4] Heng, L.K., Asseng, S., Mejahed, K. and Rusan, M. (2007) Optimizing Wheat Productivity in Two Rain-Fed Environments of the West Asia-North Africa Region Using A Simulation Model. European Journal of Agronomy, 26, 121-129.

[5] Singh, A.K., Tripathy, R. and Chopra, U.K. (2008) Evaluation of CERES-Wheat and CropSyst Models for Water-Nitrogen Interactions in Wheat Crop. Agricultural Water Management, 95, 776-786.

[6] Tsuji, G.Y., Uehara, G. and Balas, S. (1994) A Decision Support System for Agrotechnology Transfer, DSSAT, Version 3, Vol. 1-3. University of Hawaii, Honolulu.

[7] Hoogenboom, G., Jones, J.W., Cherly, H., Porter, C.H., Boote, K.J., Batchelor, B., Hunt, T., Gijsman, A., Wilkens, P., Singh, U. and Bowen, W. (2004) DSSAT Version 4 Vol. 2. University of Hawaii, Honolulu.

[8] Jones, C.A. and Kiniry, J.R. (1986) CERES-Maize: A Simulation Model of Maize Growth and Development. Texas A \& M University Press, College Station, Texas.

[9] Ritchie, J.T. and Otter, S. (1985) Description and Performance of CERES-Wheat: A User-Oriented Wheat Yield Model. In: ARS Wheat Yield Project. ARS-38. Natl Tech Info Serv, Spring-Field, Missouri, 159-175. 
[10] Hunkár, M. (1994) Validation of Crop Simulation Model CERES-Maize. Quarterly Journal of Hungarian Meteorology Series, 98, 37-46.

[11] Ruiz-Nogueira, B., Boote, K.J. and Sau, F. (2001) Calibration and Use of CROPGROSoybean Model for Improving Soybean Management under Rainfed Conditions in Galicia, Northwest Spain. Agricultural Systems, 68, 151-173. https://doi.org/10.1016/S0308-521X(01)00008-7

[12] Sarkar, R. and Kar, S. (2006) Evaluation of Management Strategies for Sustainable Rice-Wheat Cropping System Using DSSAT Seasonal Analysis. Journal of Agricultural Science, 144, 421-434. https://doi.org/10.1017/S0021859606006447

[13] Gabrielle, B. and Kengni, L. (1996) Analysis and Field-Evaluation of the CERES Models' Soil Components: Nitrogen Transfer and Transformations. Soil Science Society America Journal, 60, 142-149. https://doi.org/10.2136/sssaj1996.03615995006000010023x

[14] Gabrielle, B., Denoroy, P., Gosse, G., Justes, E. and Andersen, M.N. (1998) Development and Evaluation of a CERES-Type Model for Winter Oilseed Rape. Field Crops Research, 57, 95-111. https://doi.org/10.1016/S0378-4290(97)00120-2

[15] Zalud, Z., Stralkova, R., Pokorny, E. and Podesvova, J. (2001) Estimation of Winter Wheat Nitrogen Stress Using the CERES Crop Model. Rostlinna Vyroba, 47, 253259.

[16] Landau, S., Mitchell, R.A.C., Barnett, V., Colls, J.J., Craigon, J., Moore, K.L. and Payne, R.W. (1998) Testing Winter Wheat Simulation Models' Predictions against Observed UK Grain Yields. Agricultural and Forest Meteorology, 89, 85-99. https://doi.org/10.1016/S0168-1923(97)00069-5

[17] Saarikko, R.A. (2000) Applying a Site Based Crop Model to Estimate Regional Yields under Current and Changed Climates. Ecological Modelling, 131, 191-206. https://doi.org/10.1016/S0304-3800(00)00257-X

[18] Hoffmann, F. and Ritchie, J.T. (1993) Model for Slurry and Manure in CERES and Similar Models. Journal of Agronomy and Crop Science, 170, 330-340. https://doi.org/10.1111/j.1439-037X.1993.tb01093.x

[19] Jagtap, S.S., Abamu, F.J. and Kling, J.G. (1999) Long-Term Assessment of Nitrogen and Variety Technologies on Attainable Maize Yields in Nigeria. Agricultural Systems, 60, 77-86. https://doi.org/10.1016/S0308-521X(99)00019-0

[20] Pecetti, L. and Hollington, P.A. (1997) Application of the CERES-Wheat Simulation Model to Durum Wheat in Two Diverse Mediterranean Environments. European Journal of Agronomy, 6, 125-139. https://doi.org/10.1016/S1161-0301(96)02039-4

[21] Krupnik, T.J., Ahmed, Z.U., Timsina, J., Shahjahan, M., Kurishi, A.A.S.M., Miah, A.A., Rahman, B.M., Gathala, M.K. and McDonald, A.J. (2015) Forgoing the Fallow in Bangladesh's Stress-Prone Coastal Deltaic Environments: Effect of Sowing Date, Nitrogen, and Genotype on Wheat Yield in Farmers' Field. Field Crops Research, 170, 7-20. https://doi.org/10.1016/j.fcr.2014.09.019

[22] Kalra, N., Chakraborty, D., Sharma, A., Rai, H.K., Jolly, M., Chander, S., Ramesh Kumar, P., Bhadraray, S., Barman, D., Lal, M. and Sehgal, M. (2008) Effect of Increasing Temperature on Yield of Some Winter Crops in North-West India. Current Science, 94, 82-88.

[23] Aggarwal, P.K., Kalra, N., Chander, S. and Pathak, H. (2006) Infocrop: A Dynamic Simulation Model for the Assessment of Crop Yields, Losses Due to Pests and Environmental Impact of Agro-Ecosystems in Tropical Environments. I. Model Description. Agricultural Systems, 89, 1-25. https://doi.org/10.1016/j.agsy.2005.08.001

[24] Aggarwal, P.K., Banerjee, B., Daryaei, M.G., Bhatia, A., Bala, A., Rani, S., Chander, 
S., Pathak, H. and Kalra, N. (2006) Infocrop: A Dynamic Simulation Model for the Assessment of Crop Yields, Losses Due to Pests and Environmental Impact of AgroEcosystems in Tropical Environments. II. Performance of the Model. Agricultural Systems, 89, 47-67. https://doi.org/10.1016/j.agsy.2005.08.003

[25] Aggarwal, P.K. and Kalra, N. (1994) Analysing the Limitations Set by Climatic Factors, Genotype, Water and Nitrogen Availability on Productivity of Wheat. II. Climatically Potential Yields and Optimal Management Strategies. Field Crops Research, 38, 93-103. https://doi.org/10.1016/0378-4290(94)90003-5

[26] Kalra, N., Suneja, P., Mendiratta, N. and Gupta, N. (2013) Simulating the Impact of Climate Change and Its Variability on Growth and Yield of Crops. Climate Change and Environmental Sustainability, 1, 11-19. https://doi.org/10.5958/j.2320-6411.1.1.002

[27] Sen, R., Khan, M.S. and Islam, M.M. (2001) Effect of Different Levels of Irrigation and Fertilizer on Growth, Yield and Quality of Wheat. Bangladesh Journal of Science \& Technology, 3, 9-16.

\section{Scientific Research Publishing}

\section{Submit or recommend next manuscript to SCIRP and we will provide best} service for you:

Accepting pre-submission inquiries through Email, Facebook, LinkedIn, Twitter, etc. A wide selection of journals (inclusive of 9 subjects, more than 200 journals) Providing 24-hour high-quality service User-friendly online submission system Fair and swift peer-review system Efficient typesetting and proofreading procedure Display of the result of downloads and visits, as well as the number of cited articles Maximum dissemination of your research work

Submit your manuscript at: http://papersubmission.scirp.org/ Or contact ajps@scirp.org 